\title{
PENAMBAHAN DAGING IKAN LELE DUMBO Clarias gariepinus DENGAN KOMPOSISI YANG BERBEDA TERHADAP KARAKTERISTIK MI INSTAN
}

\section{Addition of dumbo catfish Clarias gariepinus meat with different composition on the characteristics of instant noodles}

\author{
Eko Apriansyah ${ }^{1}$, Fitra Mulia Jaya ${ }^{2}$, Helmi Haris ${ }^{3}$ \\ ${ }^{1}$ Penyuluh Kementerian Kelautan dan Perikanan \\ ${ }^{2}$ Fakultas Perikanan Universitas PGRI Palembang \\ ${ }^{3}$ Universita Djuanda \\ *Corresponding author: f_muliajaya@yahoo.com
}

\begin{abstract}
ABSTRAK
Pemanfaatan pati sagu dalam pembuatan mi merupakan salah satu upaya dalam menganekaragamkan konsumsi pangan masyarakat. Penelitian ini bertujuan untuk mengetahui mutu fisik meliputi tekstur dan warna, mutu kimia yang meliputi kadar air, abu, protein, lemak, karbohidrat dan mengetahui nilai mutu organoleptik yang meliputi warna, aroma, tekstur dan rasa. Penelitian ini dilaksanakan selama dua bulan. Perlakuan pada penelitian ini berupa penambahan daging ikan lele dumbo Clarias gariepinus pada pengolahan mi instan dengan komposisi yang berbeda (B/B) yaitu : $0 \%, 5 \%, 10 \%$ dan $15 \%$ (dari berat bahan baku). Hasil penelitian mutu fisik (tekstur antara 134,14-158,53 gf), (lightness antara 50,23-54,37 \%), (chroma antara 14,17-15,83 \%), (hue antara 70,60-75,33 \%). Mutu kimia (kadar air antara 10,56-13,63\%, kadar abu antara 0,90-2,24 \%, kadar protein antara 13,40-17,36\%, kadar lemak antara 3,50-6,19 \%, kadar karbohidrat 60,38-71,39\%). Mutu Organoleptik (warna antara 3,324,00, aroma antara 3,48-3,84, tekstur antara 3,28-3,60, rasa antara 2,68-3,60). Secara umum pada penelitian ini, perlakuan yang terbaik terdapat pada perlakuan M3 yaitu (penambahan daging ikan Lele Dumbo $10 \%$ ) dengan nilai mutu fisik (tekstur 138,73 gf), (lightness 50,30 $\%$, chroma 15,40 \%, hue 72,33 \%) mutu kimia (kadar air 12,33\%, kadar abu 1,93\%, kadar protein $16,09 \%$, kadar lemak 5,16 \%, kadar karbohidrat 64,29\%) dan mutu organoleptik (warna 4,00, aroma 3,76, tekstur 3,40, dan rasa 3,60).
\end{abstract}

Kata Kunci: Mi instan, daging ikan lele dumbo, nilai gizi.

\begin{abstract}
The use of sago starch in the manufacture of noodles is one of the efforts to diversify people's food consumption. This study aims to determine the physical quality including texture and color, chemical quality which includes water content, ash, protein, fat, carbohydrates and to determine the value of organoleptic quality which includes color, aroma, texture and taste. This research was conducted for two months. The treatment in this study was the addition of African catfish (Clarias gariepinus) meat in the processing of instant noodles with different compositions (W/B), namely: 0\%, 5\%, 10\% and 15\% (by weight of raw materials). The results of the study of physical quality (texture between 134.14-158.53 gf), (lightness between 50.23$54.37 \%$ ), (chroma between 14.17-15.83\%), (hue between 70.60-75.33\%). Chemical quality (water content between 10.56-13.63\%, ash content between 0.90-2.24\%, protein content between 13.40-17.36\%, fat content between 3.50-6.19\%, carbohydrate content 60.3871.39\%). Organoleptic quality (color between 3.32-4.00, aroma between 3.48-3.84, texture between 3.28-3.60, taste betw een 2.68-3.60). In general, in this study, the best treatment was found in the M3 treatment (10\% addition of Dumbo Catfish meat) with physical quality values (138.73 gf), (lightness 50.30\%, chroma 15.40\%, hue $72,33 \%$ ) chemical quality (12,33\%
\end{abstract}


water content, $1,93 \%$ ash content, $16.09 \%$ protein content, $5.16 \%$ fat content, $64.29 \%$ carbohydrate content) and organoleptic quality (4.00 color , 3.76 aroma, 3.40 texture, and 3.60 taste).

Keywords: Instant noodles, dumbo catfish meat, nutritional value

\section{PENDAHULUAN}

Salah satu produk olahan yang dapat dibuat dari pati sagu adalah mi instan. Sugiyono dkk. (2010) menyatakan bahwa masyarakat Indonesia telah mengalami perubahan pola konsumsi yaitu dengan menjadikan mi instan sebagai pendamping atau pengganti nasi. Mi instan yang beredar di pasaran umumnya berasal dari tepung terigu yang sampai saat ini masih harus diimpor dari luar negeri. Pemanfaatan pati sagu dalam pembuatan mi merupakan salah satu upaya dalam menganekaragamkan konsumsi pangan masyarakat.

Salah satu kekurangan pati sagu adalah rendahnya kadar protein (kurang dari $0,7 \%$ ) sehingga mi instan yang dihasilkan mengandung protein yang kecil. Upaya untuk meningkatkan kadar protein mi instan tersebut adalah dengan penambahan daging ikan Lele Dumbo Clarias gariepinus pada proses pembuatannya. Ikan Lele Dumbo Clarias gariepinus merupakan salah satu jenis ikan air tawar yang sangat digemari oleh masyarakat. Ikan Lele merupakan komoditas yang bernilai ekonomis penting dan sudah tersebar luas di Indonesia. Ikan Lele merupakan ikan air tawar yang cukup populer di Indonesia karena kandungan proteinnya tinggi dan mudah didapat (Andrianto dan Indarto, 2005).

Kandungan gizi ikan Lele mengandung air $76,0 \%$, protein $17,7 \%$, lemak $4,8 \%$ dan karbohidrat $0,3 \%$ dan mineral $1,2 \%$. Untuk mendapatkan nilai gizi mi instan yang cukup maka perlu diketahui komposisi daging ikan Lele yang ditambahkan dalam pembuatan mi instan. Berdasarkan hal ini, maka perlu dilakukan kajian penelitian tentang penambahan daging ikan Lele Dumbo Clarias gariepinus dengan komposisi yang berbeda terhadap karakteristik fisik, kimia, dan organoleptik mi instan, sehingga diharapkan produk mi instan dapat diterima dan digemari masyarakat sebagai produk olahan ikan yang dapat menunjang peningkatan konsumsi protein hewani, khususnya ikan. Tujuan dilakukannya penelitian ini adalah mengetahui nilai mutu fisik mi instan ikan Lele Dumbo yang meliputi tekstur dan warna, nilai mutu kimia mi instan ikan Lele Dumbo yang meliputi kadar air, kadar abu, kadar protein, kadar lemak dan kadar karbohidrat dan mengetahui nilai mutu organoleptik mi instan ikan Lele Dumbo (Clarias gariepinus) yang meliputi warna, aroma, tekstur dan rasa.

\section{METODOLOGI PENELITIAN Waktu dan Tempat}

Penelitian ini dilakanakan pada bulan April sampai bulan Mei di Workshop Teknologi Pengolahan Hasil Perikanan (WSTPHP) Fakultas Perikanan Universitas PGRI Palembang dan Laboratorium Mikrobiologi Hasil Pertanian Jurusan Teknologi Hasil Pertanian Fakultas Pertanian Universitas Sriwijaya Indralaya.

\section{Bahan dan Alat}

Adapun bahan baku utama yang digunakan dalam penelitian adalah tepung terigu, tepung tapioka dan ikan Lele Dumbo (Clarias gariepinus). Bahan tambahan dalam penelitian ini adalah telur, garam, air, soda abu dan bahan kimia yang digunakan untuk analisa proksimat. Sedangkan alat yang digunakan dalam penelitian ini terdiri dari : alat untuk pengolahan dan alat untuk analisa laboratorium. Alat pengolahan yang digunakan meliputi : baskom plastik, talenan, sendok, serok, sarung tangan, panci stainless, kompor gas, perangkat 
pencetak mi, blender, aluminium foil, oven dan timbangan analitik. Alat-alat yang digunakan untuk analisa di laboratorium meliputi : alat titrasi, kain kasa, cawan porselin, desikator, erlenmeyer, gelas beaker, gelas ukur, hot plate, labu kjeldahl, chroma meter, corong, muffle furnace, spatula dan pipet tetes.

\section{Metode Penelitian}

Penelitian ini dilakukan untuk menentukan komposisi penambahan daging ikan Lele Dumbo (Clarias gariepinus) yang berbeda untuk menghasilkan mi instan yang paling disukai oleh panelis berdasarkan uji organoleptik, uji fisik dan uji kimia. Penelitian ini menggunakan Rancangan Acak Lengkap (RAL) dengan 4 (empat) taraf perlakuan dan masing-masing perlakuan dilakukan 3 (tiga) kali ulangan.

Adapun taraf perlakuan penelitian ini adalah sebagai berikut :

1. Mi instan tanpa penambahan daging ikan Lele 0 \% (M1)

2. Mi instan dengan penambahan daging ikan Lele $5 \%$ dari (b/b) (M2)

3. Mi instan dengan penambahan daging ikan Lele $10 \%$ dari (b/b) (M3)

4. Mi instan dengan penambahan daging ikan Lele $15 \%$ dari (b/b) (M4)

\section{Prosedur Kerja}

Adapun tahapan proses pengolahan mi instan yang telah dimodifikasi oleh Manurung, (2009) yaitu dengan cara Ikan Lele dengan berat $2 \mathrm{~kg}$ (6 ekor $/ \mathrm{kg}$ ) disiangi (dibersihkan sirip, isi perut, kepala dan ekor) dan dicuci dengan air mengalir hingga bersih kemudian dagingnya difillet dan digiling hingga halus serta lumat dengan menggunakan blender. Kemudian daging yang telah lumat ditimbang sesuai dengan perlakuan $(0 \%, 5 \%, 10 \%$ dan $15 \%)$ dari berat bahan baku total (b/b). Pencampuran semua bahan yang digunakan sesuai dengan perlakuan yaitu daging ikan Lele $(0 \%, 5 \%, 10 \%$ dan $15 \%)$, dan tepung terigu $50 \mathrm{~g}$ yang dicampur dengan tepung tapioka $20 \mathrm{~g}$, soda abu $2 \mathrm{~g}$, garam $2 \mathrm{~g}$, air $20 \mathrm{~g}$ dan telur $6 \mathrm{~g}$. Semua bahan tersebut dicampurkan secara manual sehingga terbentuk adonan yang sempurna. Kesempurnaan adonan ditandai dengan tidak lengketnya adonan pada tangan dan dinding permukaan baskom yang digunakan sebagai tempat membuat adonan, kemudian adonan ditekan-tekan sampai permukaan adonan halus.

Adonan kemudian dibuat menjadi bulatan-bulatan kecil, kemudian digiling dengan alat pencetak mi membentuk lembaran, dilipat dua kali kemudian digiling kembali. Proses ini dilakukan beberapa kali sampai permukaan adonan benar-benar halus. Lembaran adonan didiamkan selama kurang lebih 15 menit agar proses gelatinasi lebih optimal. Setelah itu adonan digiling kembali dengan ketebalan 1,5-2 $\mathrm{mm}$ atau penggilingan dilakukan dari ketebalan (set) 1-3 mm. Lembaran adonan dipotong dengan menggunakan alat pencetak mi membentuk tali atau benang-benang, kemudian mi disusun secara manual membentuk 2 lipatan dengan panjang $12 \mathrm{~cm}$. Sampai pada tahap ini mi yang dihasilkan adalah mi mentah, kemudian didiamkan selama kurang lebih 30 menit supaya proses gelatinasinya lebih optimal.

Adonan mi yang telah dicetak tersebut, kemudian dikukus pada suhu $100^{\circ} \mathrm{C}$ selama kurang lebih 12 menit, kemudian mi yang telah dikukus ditiriskan diatas nampan plastik. Tahapan selanjutnya adalah pengovenan dilakukan selama 4 jam pada suhu $70{ }^{\circ} \mathrm{C}$. Tujuan dari pengovenan ini adalah untuk mengeringkan mi secara sempurna sehingga mi menjadi kering. Mi dipindahkan ke dalam nampan plastik kemudian didinginkan selama 15 menit. Selanjutnya mi yang telah dingin dikemas dengan menggunakan plastik mika dengan ukuran panjang $15 \mathrm{~cm}$, lebar $9 \mathrm{~cm}$ dan tinggi $3,5 \mathrm{~cm}$. 


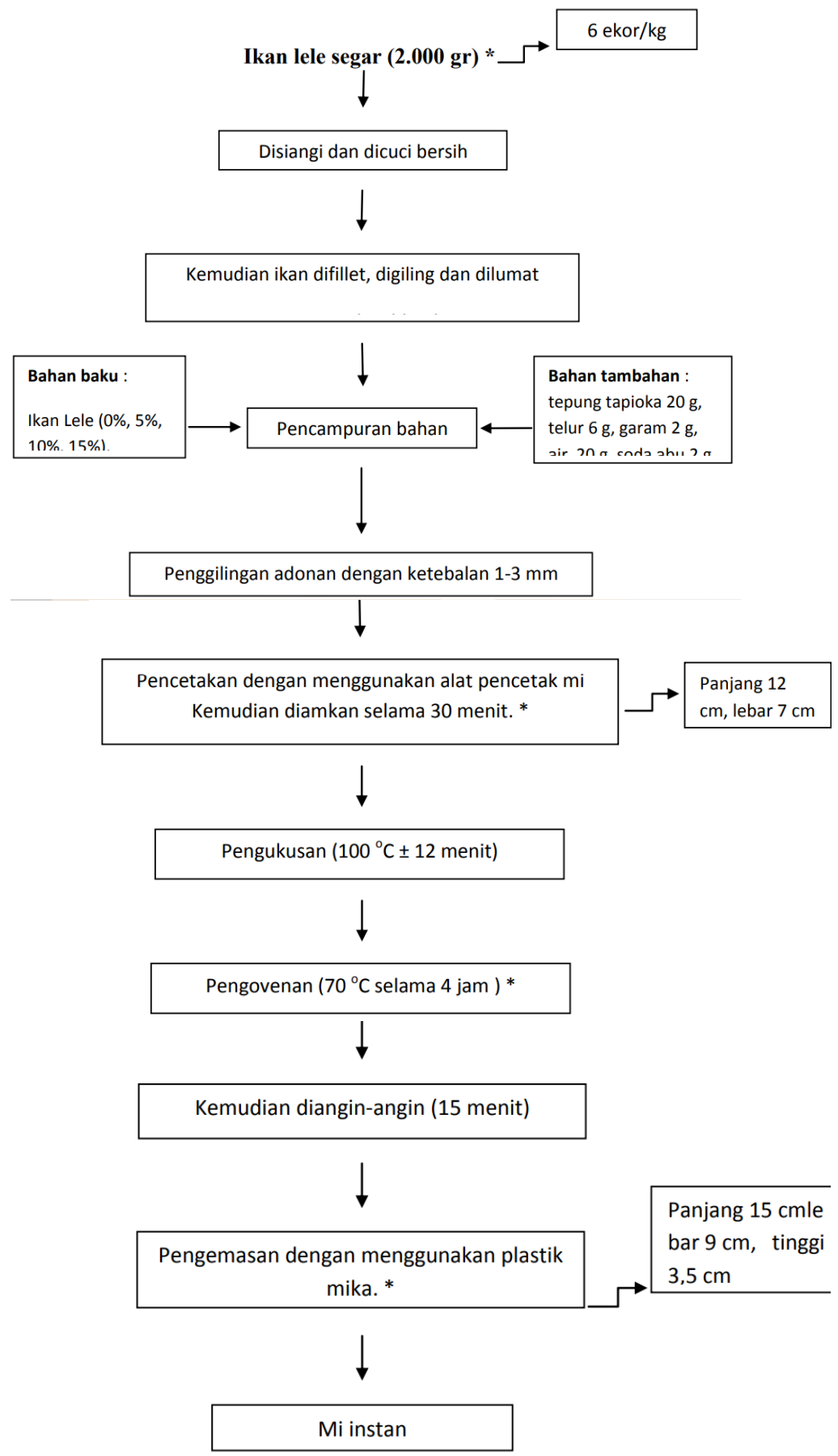

Gambar 1. Proses Pengolahan mi instan

\section{Parameter yang Diamati}

Uji fisik meliputi tekstur dan warna, Uji kimia meliputi kadar air, kadar abu, kadar protein, kadar lemak dan kadar karbohidrat dan uji organoleptik meliputi warna, aroma, tekstur dan rasa.

\section{HASIL DAN PEMBAHASAN Analisis Fisik}

Tekstur

Pengukuran tekstur mi instan menggunakan alat texture analyzer, dan dalam penggunaan alat ini memberikan pengaruh gaya terhadap produk. Adapun hasil pengukuran nilai rata-rata tekstur mi instan dengan penambahan daging ikan Lele Dumbo dapat dilihat pada Gambar 2. 


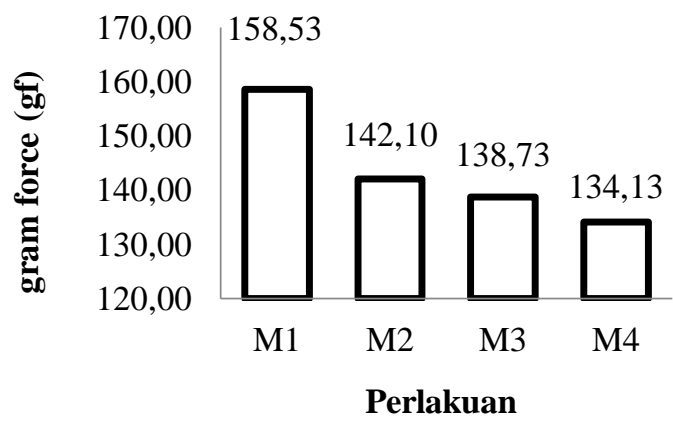

Gambar 2. Tektur mi instan pada berbagai perlakuan

Nilai rata-rata tekstur mi instan tertinggi terdapat pada perlakuan M1 (penambahan daging ikan Lele Dumbo 0 $\%$ ) yaitu 158,53 gram force (gf) sedangkan untuk nilai terendah terdapat pada perlakuan M4 (penambahan daging ikan Lele Dumbo $15 \%$ ) yaitu 134,13 gram force (gf). Hasil analisis keragaman (Lampiran 6) menunjukkan bahwa perlakuan penambahan komposisi daging ikan Lele Dumbo yang berbeda pada mi instan berpengaruh sangat nyata terhadap tekstur pada taraf uji $5 \%$. Oleh karena itu, dilakukan uji BNJ (beda nyata jujur). Hasil analisis uji lanjut Beda Nyata Jujur (BNJ), menunjukkan bahwa perlakuan M1 (penambahan daging ikan Lele Dumbo 0 $\%)$ berbeda sangat nyata dengan M2, M3, M4 (penambahan daging ikan Lele Dumbo 5, 10, $15 \%$ ), perlakuan M2 (penambahan daging ikan Lele Dumbo $10 \%$ ) berbeda sangat nyata dengan M3 dan M4 (penambahan daging ikan Lele Dumbo 10 dan $15 \%$ ), sedangkan perlakuan M3 (penambahan daging ikan Lele Dumbo 10 $\%)$ berbeda sangat nyata dengan M4 (penambahan daging ikan Lele Dumbo 15 $\%)$. Fellows (2000), menyatakan bahwa, tekstur makanan kebanyakan ditentukan oleh kandungan air yang terdapat pada produk tersebut. Semakin tinggi kandungan kadar air, maka produk tersebut semakin lembut. Pada analisis kadar air mi instan menunjukkan bahwa, semakin banyak penambahan daging ikan Lele Dumbo, kadar air nya cenderung meningkat, sehingga tekstur mi instan yang dihasilkan semakin lembut.

\section{Warna}

Pengukuran warna dilakukan dengan menggunakan alat colour reader CR-10. Alat ini bisa membedakan warna dengan berdasarkan tiga nilai yaitu : lightness (L), chroma (C), dan hue (H). Uji warna terhadap Lightness mi instan menunjukan nilai rata-rata lightness berkisar antara $50,23 \%$ sampai $54,37 \%$. Mi instan pada perlakuan M1 (penambahan daging ikan Lele Dumbo $0 \%$ ) memperoleh nilai tertinggi yaitu $54,37 \%$, sedangkan untuk nilai terendah pada perlakuan M4 (penambahan daging ikan Lele Dumbo $15 \%$ ) yaitu 50,23\% (Gambar 3). Hasil analisis keragaman menunjukan bahwa perlakuan penambahan komposisi daging ikan Lele Dumbo yang berbeda pada mi instan berbeda nyata terhadap warna (Lightness) pada taraf uji $5 \%$ yang dihasilkan. Oleh karena itu dilakukan uji lanjut Beda Nyata Jujur (BNJ). Adapun hasil analisis uji lanjut Beda Nyata Jujur (BNJ) menunjukkan bahwa perlakuan M1 (penambahan daging ikan Lele Dumbo 0 $\%$ ) berbeda sangat nyata dengan perlakuan M2, M3, M4 (penambahan daging ikan Lele Dumbo 5, 10, $15 \%$ ), perlakuan M2 (penambahan daging ikan Lele Dumbo 5 $\%$ ) berbeda sangat nyata dengan perlakuan M3, M4 (penambahan daging ikan Lele Dumbo 10, $15 \%$ ), sedangkan perlakuan M3 (penambahan daging ikan Lele Dumbo $10 \%)$ tidak berbeda nyata dengan perlakuan M4 (penambahan daging ikan Lele Dumbo $15 \%$ ). Hal ini disebabkan karena semakin tinggi komposisi daging ikan yang ditambahkan dalam mi instan, 
maka nilai lightness (L) semakin rendah, sehingga nilai lightness (L) mi instan yang dihasilkan semakin gelap karena daging ikan Lele Dumbo cenderung berwarna

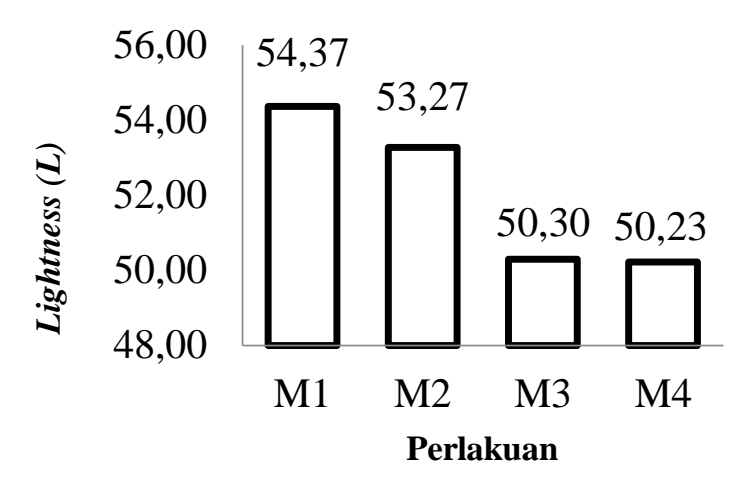

kuning kemerah-merahan dan selain itu juga dalam proses pengolahan telah terjadinya proses browning atau pencoklatan.

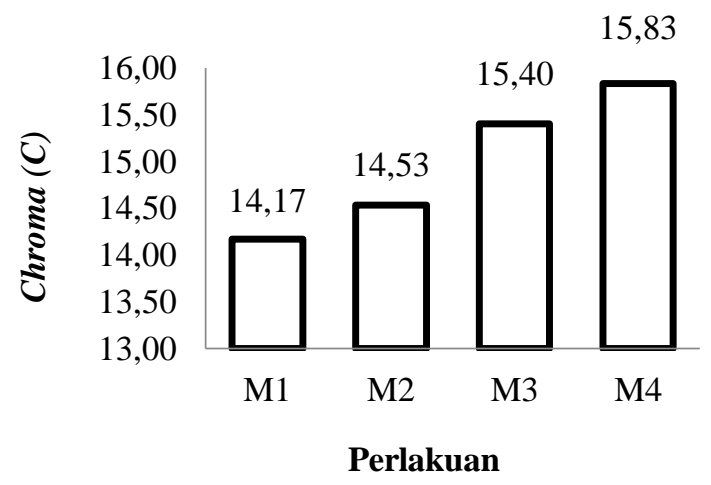

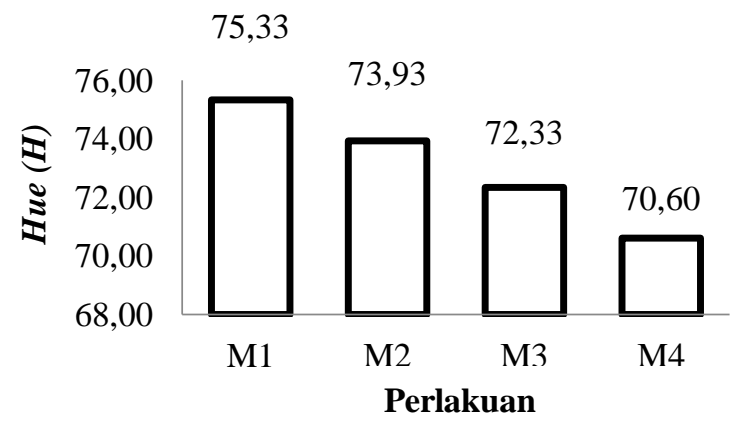

Gambar 3. Pengukuran warna dilihat berdasarkan Linghness, chroma, dan hue mi instan pada berbagai perlakuan

Bahan makanan mengandung karbohidrat dan protein akan mengalami pencoklatan non-enzimatis, apabila bahan tersebut dipanaskan (reaksi Maillard) akan dapat menghasilkan bau enak maupun tidak enak (Ubadillah, et al., 2008). Menurut Lee, (1983) dalam Aslami, (2014) menyatakan bahwa pengaruh panas selama pengeringan dapat menyebabkan terjadinya reaksi (Maillard) antara senyawa amino dengan gula pereduksi. Reaksi antara asam amino dengan gula pereduksi tersebut akan membentuk melanoidin, suatu polimer berwarna coklat yang dapat menurunkan nilai kenampakan produk. Sehingga produk yang dihasilkan akan semakin gelap. Pencoklatan juga terjadi karena reaksi antara protein, peptida dan asam amino dengan hasil dekomposisi lemak.

Uji warna terhadap Chroma mi instan menunjukan nilai rata-rata Chroma berkisar antara $14,17 \%$ sampai $15,83 \%$. Mi instan pada perlakuan M4 (penambahan daging ikan Lele Dumbo $15 \%$ ) memperoleh nilai tertinggi yaitu $15,83 \%$, sedangkan untuk nilai terendah pada perlakuan M1 (penambahan daging ikan Lele Dumbo $0 \%$ ) yaitu $14,17 \%$. Hasil analisis keragaman menunjukan bahwa perlakuan penambahan komposisi daging ikan Lele Dumbo yang berbeda pada mi instan berbeda nyata terhadap warna (Chroma) pada taraf uji $5 \%$ yang dihasilkan. Oleh karena itu dilakukan uji lanjut Beda Nyata Jujur (BNJ). Adapun hasil analisis uji lanjut Beda Nyata Jujur (BNJ) menunjukkan bahwa perlakuan M1 (penambahan daging ikan Lele Dumbo 0 $\%$ ) berbeda sangat nyata dengan M2, M3, M4 (penambahan daging ikan Lele Dumbo $5,10,15 \%$ ), perlakuan M2 (penambahan daging ikan Lele Dumbo $10 \%$ ) berbeda sangat nyata dengan M3 dan M4 (penambahan daging ikan Lele Dumbo 10 dan $15 \%$ ), sedangkan perlakuan M3 (penambahan daging ikan Lele Dumbo 10 
\%) berbeda sangat nyata dengan M4 (penambahan daging ikan Lele Dumbo 15 $\%$ ). Hal ini diduga dengan semakin banyaknya penambahan daging ikan lele dalam pembuatan mi instan, nilai Chroma mi instan semakin tinggi dan intensitas warna semakin pudar atau kusam.

Nilai Hue merupakan nilai yang mewakili panjang gelombang yang dominan yang akan menentukan apakah warna tersebut merah, hijau atau kuning (Winarno, 1991). Uji warna terhadap Hue mi instan menunjukan nilai rata-rata Hue berkisar antara 70,60 \% sampai 75,33\%. Mi instan pada perlakuan M1 (penambahan daging ikan Lele Dumbo 0 \%) memperoleh nilai tertinggi yaitu $75,33 \%$, sedangkan untuk nilai terendah pada perlakuan M4 (penambahan daging ikan Lele Dumbo 15
$\%$ ) yaitu 70,60 \%. Perubahan warna pada $\mathrm{mi}$ instan tersebut dipengaruhi oleh reaksi maillard. Reaksi maillard adalah reaksi antar karbohidrat, khususnya gula pereduksi dengan amino primer yang menghasilkan senyawa berwarna coklat yang disebut melanoidin (Winarno, 1997). Semakin tinggi komposisi daging ikan yang ditambahkan menyebabkan produk menjadi lebih gelap, sehingga semakin tinggi komposisi daging ikan yang ditambahkan maka nilai hue semakin rendah, sehingga nilai hue dapat digolongkan pada kriteria warna Yellow Red (YR) ini sesuai dengan mewakili panjang gelombang dominan yang akan menentukan warna yang dilakukan berdasarkan ketentuan seperti Tabel 2 .

Tabel 2. Penentuan Warna Berdasarkan Panjang Gelombang (Hue )

\begin{tabular}{llc}
\hline No & Kriteria Warna & Kisaran Hue \\
\hline 1. & Red Purple $(\mathrm{RP})$ & $342^{0}-18^{0}$ \\
2. & Red $(\mathrm{R})$ & $18^{0}-54^{0}$ \\
3. & Yellow Red $(\mathrm{YR})$ & $54^{0}-90^{0}$ \\
4. & Yellow $(\mathrm{Y})$ & $90^{0}-120^{0}$ \\
5. & Yellow Green $(\mathrm{YG})$ & $126^{0}-162^{0}$ \\
6. & Green $(\mathrm{G})$ & $162^{0}-198^{0}$ \\
7. & Blue Green $(\mathrm{BG})$ & $198^{0}-234^{0}$ \\
8. & Blue $(\mathrm{B})$ & $234^{0}-270^{0}$ \\
9. & Blue Purple $(\mathrm{BP})$ & $270^{0}-306^{0}$ \\
10. & Purple (P) & $306^{0}-342^{0}$ \\
\hline
\end{tabular}

Anggraini (2012) dalam Wiranata (2015).

$\begin{array}{ccc}\text { Hasil analisis } & \text { keragaman } \\ \text { menunjukkan } & \text { bahwa } & \text { perlakuan }\end{array}$ penambahan komposisi daging ikan Lele Dumbo yang berbeda pada mi instan berpengaruh sangat nyata terhadap warna (hue ) pada taraf uji $5 \%$. Oleh karena itu, dilakukan uji BNJ (beda nyata jujur). Hasil analisis uji lanjut Beda Nyata Jujur (BNJ) menunjukkan bahwa perlakuan M1 (penambahan daging ikan Lele Dumbo 0 $\%$ ) berbeda sangat nyata dengan M2, M3, M4 (penambahan daging ikan Lele Dumbo $5,10,15 \%$ ), perlakuan M2 (penambahan daging ikan Lele Dumbo $10 \%$ ) berbeda sangat nyata dengan M3 dan M4 (penambahan daging ikan Lele Dumbo 10 dan $15 \%)$, sedangkan perlakuan M3 (penambahan daging ikan Lele Dumbo 10 $\%$ ) berbeda sangat nyata dengan M4 (penambahan daging ikan Lele Dumbo 15 $\%)$. Nilai rata-rata warna $\mathrm{Heu}$ cenderung mengalami penurunan dengan semakin tingginya komposisi daging ikan Lele Dumbo yang ditambahkan.

\section{Analisa Kimia}

Analisa kimia dilakukan untuk mengetahui sifat kimia dari mi instan dengan penambahan daging ikan Lele Dumbo. Hasil dari analisis kimia mi instan dengan penambahan daging ikan Lele Dumbo disajikan pada gambar 4 berikut. 

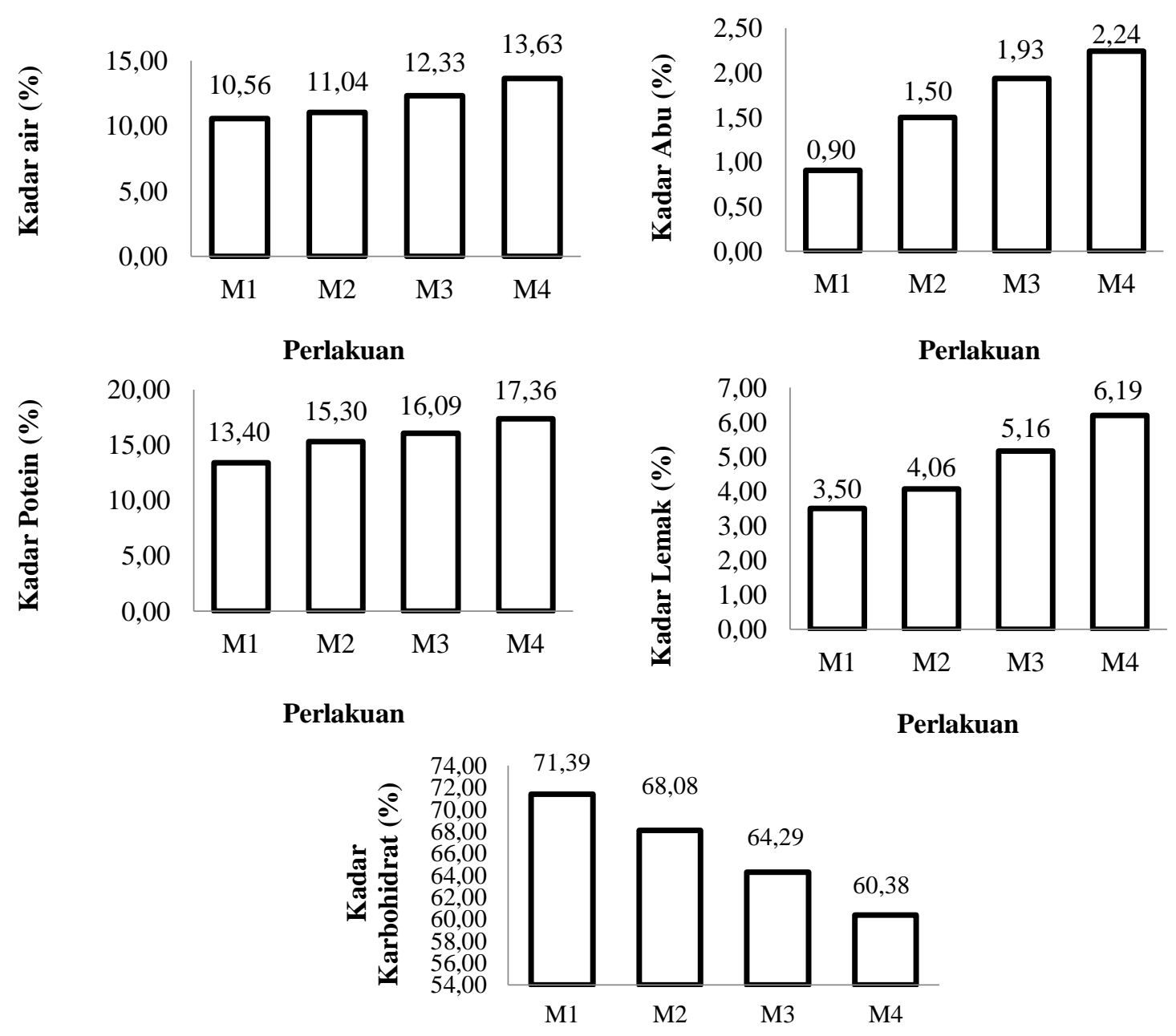

\section{Perlakuan}

Gambar 4. Sifat kimia (kadar air, kadar abu, kadar protein, kadar lemak) mi instan pada berbagai perlakuan

Nilai rata-rata kadar air mi instan tertinggi terdapat pada perlakuan M4 (penambahan daging ikan Lele Dumbo 15 $\%)$ dengan nilai rata-rata $13,63 \%$, sedangkan nilai kadar air terendah terdapat pada perlakuan M1 (penambahan daging ikan Lele Dumbo $0 \%$ ) yaitu 10,56\%. Menurut SNI 3551:2012, kadar air mi instan dengan penggorengan maksimal $8 \%$ (b/b), sedangkan yang menggunakan proses pengeringan maksimal 14,5 \% (b/b). Hasil ini menunjukkan bahwa kadar air mi instan yang dihasilkan masih dalam batasan SNI.

Hasil analisis sidik ragam menunjukkan bahwa perlakuan penambahan daging ikan Lele Dumbo dengan komposisi yang berbeda pada perlakuan berbeda sangat nyata terhadap nilai kadar air mi instan pada taraf $5 \%$. Oleh karena itu dilakukan uji lanjut Beda Nyata Jujur (BNJ). Adapun hasil analisis uji lanjut Beda Nyata Jujur (BNJ) menunjukkan bahwa perlakuan M1 (penambahan daging ikan Lele Dumbo 0 $\%$ ) berbeda sangat nyata dengan M2, M3, M4 (penambahan daging ikan Lele Dumbo $5,10,15 \%$ ), perlakuan M2 (penambahan daging ikan Lele Dumbo $10 \%$ ) berbeda sangat nyata dengan M3 dan M4 (penambahan daging ikan Lele Dumbo 10 dan $15 \%$ ), sedangkan perlakuan M3 (penambahan daging ikan Lele Dumbo 10 $\%)$ berbeda sangat nyata dengan M4 
(penambahan daging ikan Lele Dumbo 15 $\%$ ). Hal ini disebabkan kandungan air pada ikan Lele Dumbo cukup tinggi yaitu 75,1 \% (Harahap, 2010), sehingga semakin tinggi penambahan daging ikan Lele Dumbo, maka semakin tinggi nilai kadar air yang dihasilkan. Kadar air mi instan cenderung meningkat dengan penambahan daging ikan Lele Dumbo. Dalam hal ini juga disebabkan karena semakin banyak daging ikan yang ditambahkan akan menaikkan kandungan protein dalam adonan. Protein akan saling berinteraksi dan ruang antar filamen menjadi lebih besar sehingga air yang terikat pada mi akan semakin besar. Yusmarini, dkk (2013) menyatakan bahwa protein dapat saling berinteraksi dan mengakibatkan ruang antar filamen menjadi lebih besar. Hal ini berdampak pada semakin banyaknya air yang dapat ditahan sehingga jumlah air dalam mi instan semakin meningkat.

Nilai rata-rata kadar abu mi instan tertinggi terdapat pada perlakuan M4 (penambahan daging ikan Lele Dumbo 15 $\%)$ dengan nilai rata-rata 2,24 \%, sedangkan nilai kadar abu terendah terdapat pada perlakuan M1 (penambahan daging ikan Lele Dumbo $0 \%$ ) yaitu 0,90 \%. Menurut SNI 01-2974-1992, kadar abu maksimum pada mi kering yaitu $3 \%$ (b/b), hasil ini menunjukkan bahwa kadar abu mi instan yang dihasilkan masih dalam batasan SNI.

$\begin{array}{ccc}\text { Hasil } & \text { analisis sidik ragam } \\ \text { menunjukkan } & \text { bahwa }\end{array}$
penambahan daging ikan Lele Dumbo dengan komposisi yang berbeda pada perlakuan berbeda sangat nyata terhadap nilai kadar abu mi instan pada taraf $5 \%$. Oleh karena itu dilakukan uji lanjut Beda Nyata Jujur (BNJ). Adapun hasil analisis uji lanjut Beda Nyata Jujur (BNJ) menunjukkan bahwa perlakuan M1 (penambahan daging ikan Lele Dumbo 0 $\%$ ) berbeda sangat nyata dengan M2, M3, M4 (penambahan daging ikan Lele Dumbo $5,10,15 \%$ ), perlakuan M2 (penambahan daging ikan Lele Dumbo $10 \%$ ) berbeda sangat nyata dengan M3 dan M4 (penambahan daging ikan Lele Dumbo 10 dan $15 \%$ ), sedangkan perlakuan M3 (penambahan daging ikan Lele Dumbo 10 $\%)$ berbeda sangat nyata dengan M4 (penambahan daging ikan Lele Dumbo 15 \%). Menurut Sudarmadji et al. (1989) dalam Yuliana (2013), menyatakan bahwa makanan yang berasal dari hewani mengandung kadar abu yang tinggi, hal ini disebabkan oleh kandungan beberapa mineral seperti kalsium, besi dan fosfor. Dalam hal ini, kandungan kalsium, besi dan fosfor pada ikan Lele Dumbo cukup tinggi yaitu $20 \mathrm{mg}, 1,0 \mathrm{mg}$ dan $200 \mathrm{mg} / 100$ gram ikan segar (Direktorat Gizi, 1991). Maka semakin besar penambahan daging ikan Lele Dumbo pada mi instan maka semakin besar pula kadar abu yang dihasilkan.

Nilai rata-rata kadar protein mi instan tertinggi terdapat pada perlakuan M4 (penambahan daging ikan Lele Dumbo 15 $\%)$ dengan nilai rata-rata $17,63 \%$, sedangkan nilai kadar protein terendah terdapat pada perlakuan M1 (penambahan daging ikan Lele Dumbo $0 \%$ ) yaitu 13,40 $\%$. Menurut SNI 3551:2012, kadar protein mi instan minimal $8 \%$ (b/b). Hasil ini menunjukkan bahwa kadar protein mi instan yang dihasilkan masih sesuai dengan SNI.

$\begin{array}{ccr}\text { Hasil } & \text { analisis sidik } \\ \text { menunjukkan } & \text { bahwa } & \text { perlakuan }\end{array}$ penambahan daging ikan Lele Dumbo dengan komposisi yang berbeda pada perlakuan berbeda sangat nyata terhadap nilai kadar protein mi instan pada taraf $5 \%$. Oleh karena itu dilakukan uji lanjut Beda Nyata Jujur (BNJ). Adapun hasil analisis uji lanjut Beda Nyata Jujur (BNJ) menunjukkan bahwa perlakuan M1 (penambahan daging ikan Lele Dumbo 0 $\%$ ) berbeda sangat nyata dengan M2, M3, M4 (penambahan daging ikan Lele Dumbo $5,10,15 \%$ ), perlakuan M2 (penambahan daging ikan Lele Dumbo $10 \%$ ) berbeda sangat nyata dengan M3 dan M4 (penambahan daging ikan Lele Dumbo 10 dan $15 \%$ ), sedangkan perlakuan M3 (penambahan daging ikan Lele Dumbo 10 $\%$ ) berbeda sangat nyata dengan M4 
(penambahan daging ikan Lele Dumbo 15 $\%$ ). Nilai kadar protein mi instan setiap perlakuan memiliki nilai berbeda yang disebabkan oleh perbedaan komposisi daging ikan yang ditambahkan pada mi instan yaitu semakin tinggi komposisi daging ikan yang ditambahkan, maka kadar protein akan semakin tinggi. Selain itu juga ikan Lele merupakan salah satu bahan pangan dengan sumber protein yang cukup tinggi. Menurut Harahap (2010), menyatakan bahwa ikan Lele Dumbo mengandung protein cukup tinggi yaitu sebanyak $17 \%$ per 100 gram, sehingga semakin tinggi komposisi daging ikan yang ditambahkan pada mi instan maka kadar proteinnya akan semakin tinggi.

Nilai rata-rata kadar lemak mi instan tertinggi terdapat pada perlakuan M4 (penambahan daging ikan Lele Dumbo 15 $\%$ dengan nilai rata-rata $6,19 \%$, sedangkan nilai kadar lemak terendah terdapat pada perlakuan M1 (penambahan daging ikan Lele Dumbo $0 \%$ ) yaitu 3,50 \%. Hasil analisis sidik ragam menunjukkan bahwa perlakuan penambahan daging ikan Lele Dumbo dengan komposisi yang berbeda pada perlakuan berbeda sangat nyata terhadap nilai kadar lemak mi instan pada taraf $5 \%$. Oleh karena itu dilakukan uji lanjut Beda Nyata Jujur (BNJ). Adapun hasil analisis uji lanjut Beda Nyata Jujur (BNJ) menunjukkan bahwa perlakuan M1 (penambahan daging ikan Lele Dumbo 0 $\%$ ) berbeda sangat nyata dengan M2, M3, M4 (penambahan daging ikan Lele Dumbo $5,10,15 \%$ ), perlakuan M2 (penambahan daging ikan Lele Dumbo $10 \%$ ) berbeda sangat nyata dengan M3 dan M4 (penambahan daging ikan Lele Dumbo 10 dan $15 \%$ ), sedangkan perlakuan M3 (penambahan daging ikan Lele Dumbo 10 $\%$ ) berbeda sangat nyata dengan M4 (penambahan daging ikan Lele Dumbo 15 $\%)$. Perlakuan M1 (0 \%) mempunyai kandungan kadar lemak yang lebih rendah bila dibandingkan dengan mi instan dengan penambahan daging ikan Lele Dumbo. Dari hasil diatas diketahui bahwa penambahan daging ikan Lele Dumbo dapat meningkatkan kadar lemak pada mi instan. Hal ini disebabkan karena kadar lemak yang terkandung dalam ikan Lele Dumbo lebih tinggi yaitu 4,8 \% (Harahap, 2010), jika dibandingkan dengan kadar lemak yang terkandung dalam bahan baku tepung terigu yaitu 1,3 gram dalam 100 gram bahan (Wirdayanti, 2012). Sehingga semakin banyak daging ikan Lele Dumbo yang ditambahkan maka kadar lemak akan semakin tinggi.

Nilai rata-rata kadar karbohidat mi instan tertinggi terdapat pada perlakuan M1 (penambahan daging ikan Lele Dumbo 0 $\%)$ dengan nilai rata-rata $71,39 \%$, sedangkan nilai kadar karbohidrat terendah terdapat pada perlakuan M4 (penambahan daging ikan Lele Dumbo $15 \%$ ) yaitu 60,38 $\%$. Hasil analisis sidik ragam menunjukkan bahwa perlakuan penambahan daging ikan Lele Dumbo dengan komposisi yang berbeda pada perlakuan berbeda sangat nyata terhadap nilai kadar karbohidrat mi instan pada taraf $5 \%$. Oleh karena itu dilakukan uji lanjut Beda Nyata Jujur (BNJ). Adapun hasil analisis uji lanjut Beda Nyata Jujur (BNJ) menunjukkan bahwa perlakuan M1 (penambahan daging ikan Lele Dumbo $0 \%$ ) berbeda sangat nyata dengan M2, M3, M4 (penambahan daging ikan Lele Dumbo 5, 10, $15 \%$ ), perlakuan M2 (penambahan daging ikan Lele Dumbo $10 \%$ ) berbeda sangat nyata dengan M3 dan M4 (penambahan daging ikan Lele Dumbo 10 dan $15 \%$ ), sedangkan perlakuan M3 (penambahan daging ikan Lele Dumbo $10 \%$ ) berbeda sangat nyata dengan M4 (penambahan daging ikan Lele Dumbo $15 \%$ ). Nilai kadar karbohidrat mi instan pada setiap perlakuan memiliki nilai berbeda yaitu semakin banyak daging ikan yang ditambahkan maka semakin rendah kadar karbohidrat. Dalam hal ini kandungan karohidrat yang terdapat dalam ikan Lele Dumbo sangat sedikit yaitu sebesar 0,3 \% (Harahap, 2010). Hal ini juga disebabkan oleh karbohidrat seringkali bergabung dengan protein menjadi glikoprotein. Menurut Martoharsono dan Mulyono (1976), 
karbohidrat seringkali bergabung dengan senyawa golongan lain seperti protein dengan nama glikoprotein. Selain itu juga dalam pengolahan mi instan tersebut dilakukan proses pengeringan. Menurut Lee, (1983) dalam Aslami, (2014) menyatakan bahwa pengaruh panas selama pengeringan dapat menyebabkan terjadinya
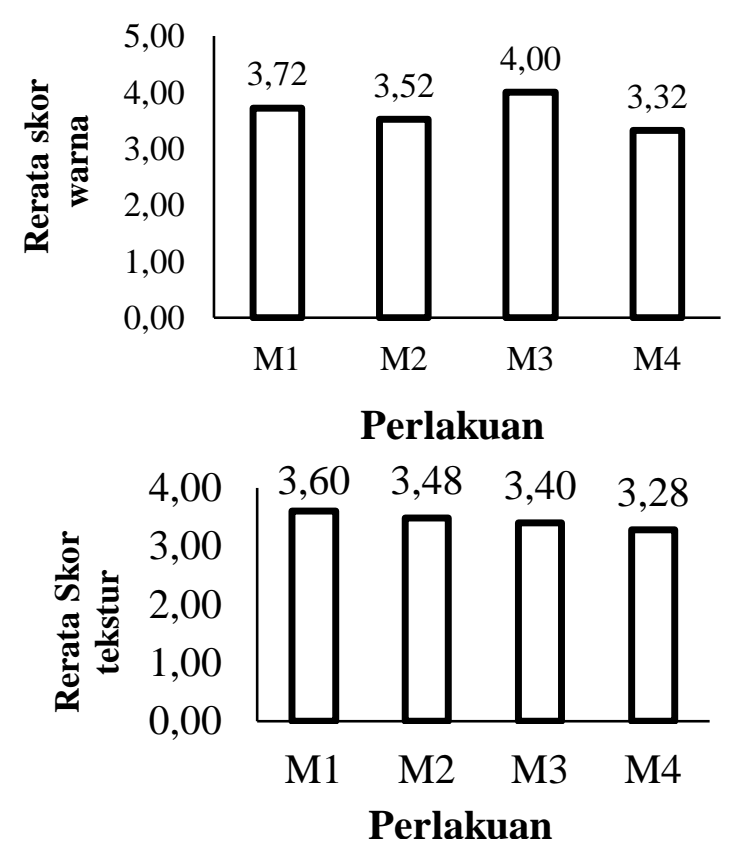

reaksi (Maillard) antara senyawa amino dengan gula pereduksi, sehingga dari reaksi (Maillard) tersebut dapat menyebabkan menurunnya kandungan kadar karbohidrat.

\section{Uji Organoleptik}

Warna
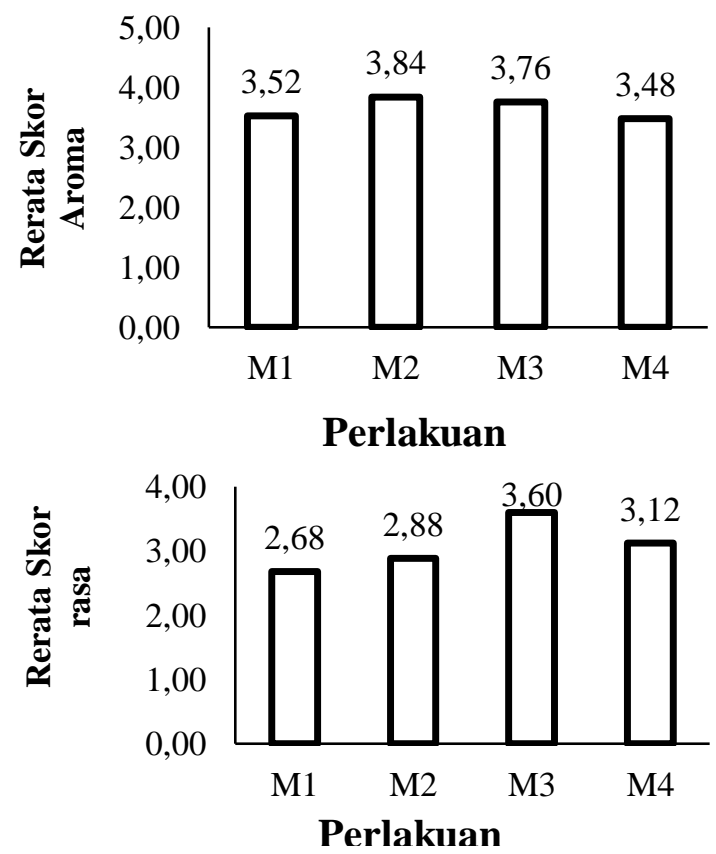

Gambar 4. Uji organoleptik berdasarkan skoring warna, aroma, tekstur dan rasa mi instan pada berbagai perlakuan

Hasil uji kesukaan terhadap mi instan menunjukkan bahwa nilai rata-rata kesukaan terhadap warna mi instan dengan penambahan daging ikan Lele Dumbo adalah 3,32 (netral) sampai 4,00 (suka). Tingkat tertinggi tedapat pada perlakuan M3 (penambahan daging ikan Lele Dumbo $10 \%$ ) dan terendah terdapat pada perlakuan M4 (penambahan daging ikan Lele Dumbo $15 \%)$. Hasil uji lanjut warna mi instan menunjukan bahwa perlakuan penambahan daging ikan Lele Dumbo berbeda nyata terhadap tingkat kesukaan pada warna yang dihasilkan mi instan. Hasil uji lanjut bahwa perlakuan M3 berbeda nyata pada tingkat kesukaan terhadap warna yang dihasilkan dibandingkan dengan perlakuan M1, M2, dan M4. Hal ini diduga bahwa penambahan daging ikan Lele Dumbo sebanyak $10 \%$ (M3) merupakan formulasi yang optimal sehingga mi instan yang dihasilkan memiliki warna yang dipaling disukai oleh panelis. Hasil pengujian kesukaan spesifikasi warna mi instan pada pelakuan M4 (penambahan daging ikan Lele Dumbo $15 \%$ ) paling rendah karena memiliki warna cenderung gelap dan warna paling tinggi adalah mi instan pada pelakuan M3 (penambahan daging ikan Lele Dumbo $10 \%)$ karena warna kekuningan lebih disukai panelis. Sedangkan untuk perlakuan M1 (penambahan daging ikan Lele Dumbo 0 $\%$ ) dan M2 (penambahan daging ikan Lele Dumbo $5 \%$ ) warna mi yang dihasilkan cenderung putih pudar, karena komposisi daging ikan Lele Dumbo yang ditambahkan sedikit. Hasil secara keseluruhan panelis menyukai mi instan 
dengan komposisi $10 \%$ sehingga menjadi komposisi terbaik menurut panelis.

Hasil pengujian organoleptik terhadap aroma mi instan menujukan bahwa perlakuan penambahan daging ikan Lele Dumbo dengan komposisi yang berbeda memberikan pengaruh tidak nyata terhadap nilai aroma mi instan. Hal ini menunjukan bahwa terdapat tingkat kesukaan yang cenderung sama terhadap aroma mi instan yang dihasilkan, maka tidak dilakukan uji lanjut.

Hasil uji kesukaan terhadap mi instan menunjukkan bahwa nilai rata-rata kesukaan terhadap tekstur mi instan dengan penambahan daging ikan Lele Dumbo adalah 3,28 (netral) sampai 3,60 (agak suka). Tingkat tertinggi tedapat pada perlakuan M1 (penambahan daging ikan Lele Dumbo $0 \%$ ) dan terendah terdapat pada perlakuan M4 (penambahan daging ikan Lele Dumbo $15 \%$ ).

Terdapat hasil uji yang berbeda antara uji fisik dan uji organoleptik pada parameter tekstur, dimana pada uji fisik menunjukan bahwa perlakuan penambahan daging ikan Lele Dumbo dengan komposisi yang berbeda memberikan pengaruh nyata terhadap nilai tekstur, sedangkan pada hasil uji organoleptik terhadap teksur mi instan menujukan bahwa perlakuan penambahan daging ikan Lele Dumbo dengan komposisi yang berbeda memberikan pengaruh tidak nyata terhadap nilai tekstur yang dihasilkan. Hal ini menunjukan bahwa terdapat tingkat kesukaan yang juga cenderung sama terhadap tekstur mi instan yang dihasilkan, maka tidak dilakukan uji lanjut. Selain itu juga, hal ini diduga disebabkan oleh kurangnya tingkat ketelitian panelis terhadap uji organoleptik pada parameter tekstur, sehingga nilai tekstur yang dihasilkan tidak berpengaruh nyata terhadap produk mi instan.

Hasil uji kesukaan terhadap mi instan menunjukkan bahwa nilai rata-rata kesukaan terhadap rasa mi instan dengan penambahan daging ikan Lele Dumbo adalah 2,68 (netral) sampai 3,60 (agak suka). Tingkat tertinggi tedapat pada perlakuan M3 (penambahan daging ikan Lele Dumbo $10 \%$ ) dan terendah terdapat pada perlakuan M1 (penambahan daging ikan Lele Dumbo $0 \%$ ). Penelis lebih cenderung agak suka terhadap perlakuan M3 (penambahan daging ikan Lele Dumbo $10 \%$ ) dibandingkan dengan perlakuan M1, M2, dan M4 dikarenakan pada perlakuan M3 rasa mi instan yang dihasilkan masih khas seperti rasa mi instan yang ada dipasaran pada umumnya. Hasil pengujian organoleptik terhadap rasa mi instan menujukan bahwa perlakuan penambahan daging ikan Lele Dumbo dengan komposisi yang berbeda memberikan pengaruh tidak nyata terhadap nilai rasa mi instan yang dihasilkan, dimana dari hasil pengolahan data uji Friedman - Conover didapat nilai $\mathrm{T}=2,07$ lebih kecil dari $\mathrm{F}$ Tabel $(\mathrm{K} 1=3$, $\mathrm{K} 2=72)=2,68$ maka tidak dilakukan uji lanjut.

\section{KESIMPULAN}

Perlakuan penambahan daging ikan Lele Dumbo (Clarias gariepinus) dengan komposisi yang berbeda terhadap karakteristik mi instan berpengaruh nyata terhadap parameter fisik yaitu tekstur dan warna (lightness, chroma dan hue ), parameter kimia yaitu kadar air, abu, protein, lemak dan karbohirat, serta berpengaruh nyata terhadap parameter organoleptik yaitu warna dan berpengaruh tidak nyata terhadap aroma, tekstur dan rasa. Secara umum perlakuan terbaik terdapat pada perlakuan M3 (penambahan daging ikan Lele Dumbo $10 \%$ ), dengan hasil uji fisik yaitu : tekstur 138,73 gf, warna (lightness 50,30\%, chroma 15,40\%, hue 72,33\% (Yellow Red), hasil uji kimia yaitu : kadar air 12,33\%, abu 1,93\%, protein $16,09 \%$, lemak $5,16 \%$, karbohidrat $64,29 \%$ dan hasil uji organoleptik yaitu : warna 4,00, aroma 3,76, tekstur 3,40, dan rasa 3,60 .

\section{DAFTAR PUSTAKA}

Andrianto, T dan Indarto, N. 2005. Pedoman Praktis Budidaya Ikan Lele. Absolut, Yogyakarta. 
Aslami, H. 2014. Penambahan Tepung Keong Tutut dengan Komposisi yang Berbeda Terhadap Karakteristik Kerupuk. Skripsi. Fakultas Perikanan Universitas PGRI Palembang. Palembang. (tidak dipublikasikan).

BSN. 1992. Standar Nasional Indonesia (SNI 01-2974-1992). Mi Kering. Badan Standardisasi Nasional. Jakarta.

BSN. 2012. Standar Nasional Indonesia (SNI 3551:2012). Mi Instan. Badan Standardisasi Nasional. Palembang.

Fellows, P.J. 2000. Food Processing Technology Principle and Practice. Secound Edition. Woodhead Publishing Limited and CRC Press LLC, Boca Raton, Cambridge.

Harahap. 2010. Perubahan Karakteristik Fisik dan Kimia Surimi Hasil Pengkomposisian Ikan Mas (Cyprinus carpio) dan Ikan Lele Dumbo (Clarias gariepinus) Selama Penyimpanan Suhu Dingin. Skripsi. Departemen Teknologi Hasil Perairan. Fakultas Perikanan dan Ilmu Kelautan. Institut Pertanian Bogor. Bogor.

Manurung, N.V.W. 2009. Pengaruh Penambahan Carboxy Methyl Cellulose (CMC) dan Daging Ikan Nila (Oreochromis niloticus) Terhadap Mutu Mie Kering. Skripsi. Fakultas Perikanan dan Ilmu Kelautan Universitas Riau. Pekanbaru. (tidak dipublikasikan).

Martoharsono, S dan Mulyono. 1976. Petunjuk Praktikum Biokimia. Universitas Gadjah Mada, Yogyakarta.
Sugiyono, S.E. Wibowo, S. Koswara, S. Herodian, S.Widowati, dan B. A. S. Santosa. 2010. Pengembangan Produk Mi Instan dari Tepung Hotong (Setaria italica beauv.) dan Pendugaan Umur Simpannya dengan Metode Akselerasi. Jurnal Teknologi dan Industri Pangan, Vol 21 No. 1, 2011, Hal 45-50.

Ubadillah, A dan Hersoelistyorini, W. 2008. Kadar Protein dan Sifat Organoleptik Nugget Rajungan dengan Substitusi Ikan Lele (Clarias gariepinus). Jurnal Teknologi Pangan. Universitas Muhammadiyah Semarang. Semarang.

Winarno F.G. 1991. Kimia Pangan dan Gizi. Gramedia. Jakarta.

Wirdayanti. 2012. Studi Pembuatan Mie Kering dengan Penambahan Pasta Ubi Jalar (Ipomoea batatas), Pasta Kacang Tunggak dan Pasta Tempe Kacang Tunggak (Vigna unguiculata, L). Skripsi. Fakultas Pertanian Universitas Hasanuddin. Makassar. (tidak dipublikasikan).

Yuliana, R. 2013. Karakteristik Bakso Ikan Lele (Clarias batracus) dan Ikan Patin (Pangasius hypophthalmus) dengan Konsentrasi Tepung Tapioka yang Berbeda. Skripsi. Fakultas Perikanan Universitas PGRI Palembang. Palembang. (tidak dipublikasikan).

Yusmarini., U. Pato., S. Anirwan dan H. Siregar. 2013. Mi Instan Berbasis Pati Sagu dan Ikan Patin serta Pendugaan Umur Simpan dengan Metode Akselerasi. Jurnal Teknologi dan Industri Pertanian Indonesia. Vol. (5) No.2, Fakultas Pertanian. Universitas Riau. Pekanbaru. 